\title{
Kotieläintalouden rakennemuutos - millainen tila jatkaa ja missä?
}

Jarkko K. Niemi $^{1)}$, Alina Sinisalo ${ }^{1)}$, Heikki Lehtonen ${ }^{1)}$, Tapani Lyytikäinen ${ }^{2)}$, Leena Sahlström ${ }^{2)}$ ja Terhi Virtanen ${ }^{2)}$

1) MTT Taloustutkimus, Latokartanonkaari 9,00790 Helsinki, Finland, alina.sinisalo@mtt.fi, jarkko.niemi@mtt.fi,heikki.lehtonen@mtt.fi

2) Evira, Riskinarvioinnin tutkimusyksikkö, Mustialankatu 3, 00790 Helsinki, Finland, tapani.lyytikainen@evira.fi,leena.sahlstrom@evira.fi,terhi.virtanen@evira.fi

\section{Tiivistelmä}

Kotieläintilojen määrä Suomessa on puolittunut noin kerran kymmenessä vuodessa. Samalla tilojen keskikoko on kasvanut ja suurten tilojen merkitys on lisääntynyt. Kotieläintuotannon rakennekehitys on herättänyt kysymyksiä siitä, ovatko eläintauteihin liittyvät riskit samalla kasvaneet tai muuttuneet.

Tässä tutkimuksessa selvittiin miten kotieläintuotannon rakenne (tilojen määrä, tilakoko, tuotannon alueellinen sijoittuminen) on muuttunut ja millaisia muutostekijöitä siihen liittyy. Tutkimusaineistona käytettiin kotieläintiloja koskevia rekisteriaineistoja vuosilta 1997 ja 2009 sekä simulaatiomallien avulla kerättyä tietoa. Muutostrendien hahmottamisessa hyödynnettiin osittaisen tasapainon mallia (DREMFIA) ja asiantuntijatyöpajoja.

Logistinen regressio sika- ja nautakarjatiloista vuosina 1997 ja 2009 paljasti, että tila jatkoi sitä todennäköisemmin tuotantoa mitä suurempi se oli. Esimerkiksi lähes kaikilla vuonna 1997 yli 50 lehmää pitäneillä tiloilla oli nautoja 2009. Kotieläintilojen määrä $10 \mathrm{~km}$ säteellä tilasta vaikutti eri tuotantosuunnissa eri tavoin. Nautatilojen jatkaminen oli hieman todennäköisempää alueilla, joilla oli vähän nautatiloja. Emakkojen pito vuonna 1997 lisäsi sikatuotannon jatkamisen todennäköisyyttä ja emo- ja lypsylehmien pito nautakarjatuotannon jatkamisen todennäköisyyttä. Tilat, joilla oli vuonna 1997 sekä sikoja että nautoja, olivat todennäköisempiä jatkajia kuin yhtä eläinlajia pitäneet tilat. Makrotason muuttujien (mm. työttömyysaste) vaikutus vaihteli tuotantosuunnittain. Sikatuotannon jatkaminen oli yleisempää alueilla, joilla kotitalouksien käytettävissä oleva tulo vuonna 1997 oli pieni.

Jatkaneiden tilojen koon kasvussa oli paljon vaihtelua. Tilat olivat tuotantokeskittymissä jo vuonna 1997 hieman keskimääräistä suurempia. Tuotannon mahdollinen alueellinen keskittyminen johtunee ensisijassa paikallisista eroista tilakoon kasvussa, ei niinkään erilaisesta tilojen määrän kehityksestä.

Keskimääräisen tilakoon arvioitiin kasvavan nykyvauhdilla tai jopa nopeammin ja tilojen erikoistumisen lisääntyvän edelleen. Pieniä tiloja poistuu toimialalta, suuria tulee tilalle ja osa jatkajista laajentaa tiettyä tuotannonhaaraa.

Eviran ja MTT:n simuloiman aineiston mukaan suu- ja sorkkataudin kaltaisen herkästi tarttuvan eläintaudin esiintymisestä seuraavat taloudelliset menetykset ovat yhteydessä tautia levittävien kontaktien (eläinkuljetukset, maitoautot, vierailijat yms.) ja tartunnan saaneen tilan lähistöllä sijaitsevien muiden kotieläintilojen määrään. Kontaktien määrä kasvaa tilan koon kasvaessa, mutta tilan koko itsessään ei ole hyvä taudinlevityskyvyn indikaattori. Suurissa tuotantoyksiköissä ja alueellisissa tuotantokeskittymissä eläintaudeille voi altistua entistä suurempi eläinmäärä. Voi käydä myös niin että koko kontaktiverkosto muuttaa luonnettaan ja esimerkiksi eläinkuljetusten kautta syntyvät tilojen väliset kontaktit harvenevat.

Asiasanat: kotieläintuotanto, rakennemuutos, tilakoko, alueellinen keskittyminen, erikoistuotantomuodot 


\section{Johdanto}

Kotieläintilojen määrä Suomessa on puolittunut noin kerran kymmenessä vuodessa. Samalla tilojen keskikoko on kasvanut, ja suurten tilojen merkitys on lisääntynyt. Kehitys on jatkunut jo pitkään, joskin vuosikymmenten välillä on jonkin verran vaihtelua (Hassinen 1980, Lehtonen ym. 2002, Pyykkönen ym. 2010). Myös muissa pohjoismaissa rakennekehitys on ollut samansuuntaista (Pyykkönen ym. 2010)

Alueittain tarkasteltuna sikojen määrä on lisääntynyt Länsi-Suomessa. Sen sijaan nautatuotanto on vähentynyt koko maassa, voimakkaimmin Kaakkois-Suomessa. Lehtosen ja Pyykkösen (2005) mukaan tuotannon kehityksessä onkin suuria paikallisia eroja. Tilakoon kasvun ja kotieläintuotannon alueellisen keskittymisen on arvioitu jatkuvan ja jopa kiihtyvän. Esimerkiksi Suomen ja EU:n komission sopimus Etelä-Suomen 141-tuista edellyttää korkeimpien investointitukien käyttöä A- ja Btukialueilla, mikä voi osaltaan kiihdyttää rakennekehitystä.

Rakennekehitys on elintarviketuotannon keino sopeutua kiristyvään kilpailuun ja on siksi tärkeää eläintuotannon säilyvyyden kannalta. Sen hyötyjä ja haittoja ei kuitenkaan ole tutkittu perusteellisesti. Rakennekehityksellä voidaan saavuttaa monia hyötyjä, kuten ottaa käyttöön työtä säästäviä tai eläinten hyvinvointia parantavia tuotantoteknologioita, joiden käyttö ei olisi mahdollista entisellä tuotantorakenteella. Rakennekehitys voi kuitenkin lisätä eläintautiriskejä, sillä suurissa tuotantoyksiköissä ja alueellisissa tuotantokeskittymissä eläintaudeille voi altistua entistä suurempi eläinmäärä.

Kotieläintuotannon rakennekehitys onkin herättänyt kysymyksiä siitä, ovatko eläintauteihin liittyvät riskit samalla kasvaneet tai muuttuneet. Kirjallisuudessa on viitteitä siitä, että tuotannon rakenne vaikuttaa merkittävästi eläintautien aiheuttamaan epidemiologiseen ja taloudelliseen riskiin $(\mathrm{mm}$. Mangen 2002, Backer ym. 2007, Lyytikäinen ja Kallio 2009, Niemi ym. 2008, Lyytikäinen ym. 2011). Joidenkin arvioiden mukaan eläintautiriskin kustannukset voivat olla Euroopan eläintiheimmillä alueilla useita prosentteja, jopa kymmeniä prosentteja eläinten arvosta (van Asseldonk ym. 2003a, 2003b). Tautiriskien lisäksi mahdollisen tuotannon keskittymisen on arvioitu voivan aiheuttaa ympäristöongelmia, koska kotieläintilojen päästöt voivat nousta pistemäisesti. Eläintautiriskien ohella ratkaisuja onkin haettu eri tavoin myös ympäristöhaittojen vähentämiseen (vrt. esim. Luostarinen ym. 2011).

Maatalouden rakennekehitys on luonteeltaan sarja käytännössä peruuttamattomia luopumis- ja investointipäätöksiä. Jotta voitaisiin tarkastella rakennekehityksen vaikutusta riskeihin, on ensin selvitettävä, miten tilarakenne on näiden päätösten seurauksena muuttunut. Tämän tutkimuksen tavoitteena oli selvittää, miten kotieläintuotannon rakenne (tilojen määrä, tilakoko, tuotannon alueellinen sijoittuminen ja erikoistuotantomuodot) on muuttunut ja millaisia muutostekijöitä siihen liittyy. Lopuksi pohditaan rakennemuutoksen kohteena olevien ominaisuuksien yhteyttä eläintautien leviämisen kannalta tärkeisiin tekijöihin. Tutkimusaineistona käytettiin kotieläintiloja koskevia rekisteriaineistoja vuosilta 1997 ja 2009 sekä simulaatiomallien avulla kerättyä tietoa. Muutostrendien hahmottamisessa hyödynnettiin mm. alueellista dynaamista Suomen maatalouden osittaisen tasapainon mallia (DREMFIA) ja asiantuntijatyöpajoja.

\section{Aineisto ja menetelmät}

Rakennekehitystä tarkasteltiin sekä toteutuneen että ennakoidun kehityksen perusteella. Menneen kehityksen osalta tutkimusaineistona käytettiin Maatilarekisteristä saatua tilakohtaista aineistoa, joka sisälsi tiedot mm. tilojen sika- ja nautamääristä vuosina 1997 (41 962 tilaa) ja 2009 (14 140 tilaa). Tiloille haettiin niiden rekisteriin merkitty sijaintipiste (pituus- ja leveyskoordinaatti), tai sen puuttuessa rekisteriin merkityn osoitteen sijaintipiste. Tilakohtaista aineistoa täydennettiin seutukunnittaisella aineistolla, joka sisälsi tietoa tilan sijaintialueen työttömyysasteesta ja kotitalouksien tulotasosta vuonna 1997 alueella, sekä alueellisilla pellon hintatiedoilla vuonna 1997.

Aineistoon sovitettiin logistiset regressiomallit, joilla selitettiin tilan todennäköisyyttä jatkaa eläintyypin pitoa vuonna 2009. Selittävinä muuttujina olivat tilan ominaisuudet vuonna 1997, muiden tilojen ja niillä olevien eläinten määrä $10 \mathrm{~km}$ säteellä tilasta vuonna 1997 sekä työttömyysastetta, kotitalouksien tulotasoa ja pellon hintaa alueella kuvaavat muuttujat. Kaikista tilastollisen mallin jatkuvista muuttujista otettiin logaritmimuunnos ja sen jälkeen nämä muuttujat standardisoitiin jakamalla tunnusluvut saman tuotantosuunnan tilojen keskiarvolla ja vähentämällä niistä keskiarvot. Taulukossa 1 raportoitavissa jatkuvissa muuttujissa yhden yksikön muutos tunnusluvussa vastaakin yhden keskihajontayksikön muutosta logaritmimuunnetussa tunnusluvussa. 
Tila- ja eläinmäärien sekä tilakoon kehitystä mallinnettiin DREMFIA-sektorimallilla vuoteen 2020 asti (Lehtonen 2004). Lisäksi hyödynnettiin kahden kotieläintuotannon asiantuntijoille suunnatun työpajan tuloksia. DREMFIA-sektorimalli tuottaa EU-tason tuottajahinta- ja tuotantopanoshintaskenaarioille ehdolliset tuotanto- ja eläinmääräennusteet tietyn maatalouspolitiikan vallitessa. Skenaarioissa oletettiin tiedossa oleva maatalouspolitiikka vuoteen 2013 asti. Tuotanto sijoittuu mallissa vähitellen suhteellisesti edullisimmille alueille ja kokonaistuotanto kilpailee tuonnin kanssa. Arviot kotieläintalouden tuotannon kokonaismäärän kehityksestä tehtiin neljälle eri suuralueelle (Etelä-Suomi, Sisä-Suomi, Pohjanmaa, Pohjois-Suomi).

DREMFIA-sektorimalli ottaa endogeenisesti (ehdollisena tuotannon suhteelliselle kannattavuudelle hintojen, tukien ym. vaihdellessa) huomioon tilaluokkajakauman muutoksen lypsykarjataloudessa. Tämä on tärkeää, sillä lypsykarjataloudessa arvioidaan tapahtuvan merkittävä tilaluokkajakauman muutos vuoteen 2020.

\section{Tulokset ja tulosten tarkastelu \\ Tila-ja eläinmäärän kehitys}

Tilakohtaisen aineiston mukaan sikoja pitäneiden tilojen määrä vähentyi 60 \% vuodesta 1997 vuoteen 2009. Nautoja pitäneiden tilojen määrä puolestaan väheni $54 \%$. Sen sijaan sikojen ja nautojen määrät Suomessa muuttuivat tarkastelujaksolla vain vähän. Sekä sikoja että nautoja pitäneiden sekatilojen määrä vähentyi tarkastelujakson aikana 1/8-osaan ja eläinten määrä vähentyi yhteen kolmasosaan. Tuotantonsa rekisterimerkintöjen perusteella vuosien 1997 ja 2009 välillä lopettaneiden tilojen eläinmäärä oli alle kolmasosa tuotantoa jatkaneiden tilojen eläinmäärästä. Esimerkiksi lähes kaikki vuonna 1997 yli 50 lehmää pitäneet tilat pitivät nautoja vielä 2009. Aineistossa oli noin 900 sikoja tai nautoja pitänyttä tilaa, joista ei ollut rekisterimerkintöjä vuonna 1997. Näiden "uusien" tilojen eläinmäärä oli yli seitsemänkertainen lopettaneisiin verrattuna.

Tilatiheys (tilaa per km² $10 \mathrm{~km}$ säteellä tarkasteltavasta tilasta) oli suurempi vuonna 1997 kuin 2009, koska tiloja lopetti toimintansa sekä tilatiheillä että -harvoilla alueilla. Tarkasteltaessa vuoden 1997 tilatiheyttä erikseen vuoteen 2009 asti tuotantoa jatkaneiden sekä sitä ennen tuotantonsa lopettaneiden tilojen tilatiheyttä havaittiin, että jakaumissa oli melko pieniä eroja. Tuotantoa jatkaneiden ja tuotannon lopettaneiden tilojen tilatiheys vuonna 1997 määräytyy sen mukaan, kuinka paljon $10 \mathrm{~km}$ säteellä tilasta on ollut kotieläintiloja vuonna 1997 (ml. lopettaneet ja jatkaneet tilat). Erot johtuvat siitä, että jatkaneet ja lopettaneet tilat voivat sijaita tilatiheydeltään erilaisilla alueilla (kuva 1).

DREMFIA-simulaatiotulosten mukaan (kuva 2) maidontuotantoa, muuta nautakarjataloutta sekä sikataloutta harjoittaneiden tilojen lukumäärät jatkavat edelleen laskuaan. Myös sikojen ja lypsylehmien odotetaan vähenevän vuoteen 2020 mennessä. Sen sijaan emolehmätuotanto näyttäisi lisääntyvän. Sikataloudessa kokonaistuotanto ja eläinmäärä voi Suomessa edelleen vähentyä, jos lihan hinta ei nouse viljan hintaa vastaavasti. Pääsääntöisesti sikojen määrä kasvaa jatkossakin, ainakin lievästi, Lounais-Suomessa ja Pohjanmaalla sijaitsevilla vahvoilla tuotantoalueilla. Tätä suhteellisesti suurempi muutos tapahtuu lypsykarjataloudessa, jossa lypsylehmien lukumäärä ja erityisesti tuotanto lisääntyy osissa Pohjanmaata ja Pohjois-Savoa (C2-tukialueet). Maidontuotanto ja nautojen määrä vähentynee edelleen lievästi Etelä-Suomessa, joskin lehmien määrä saattaa joillain alueilla lisääntyä. 


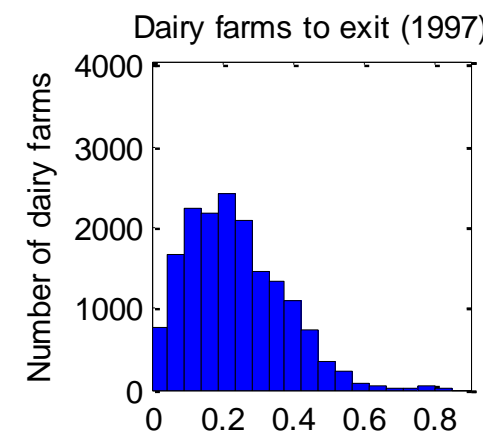

Farms $/ \mathrm{km}^{2}$ in 1997

Pig farms to exit (1997)

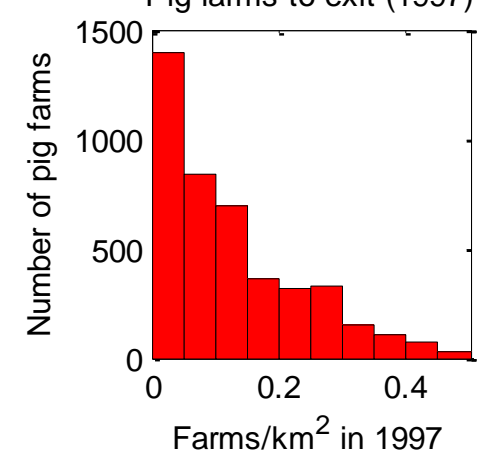

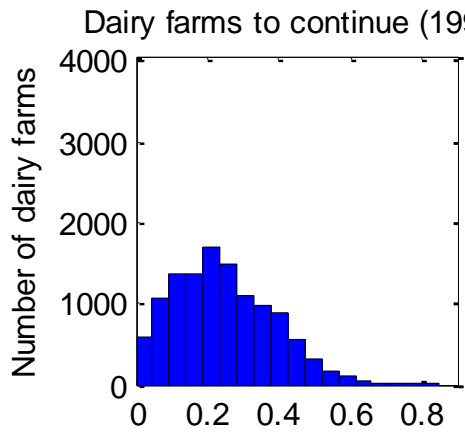

Farms $/ \mathrm{km}^{2}$ in 1997

Pig farms to continue (1997)

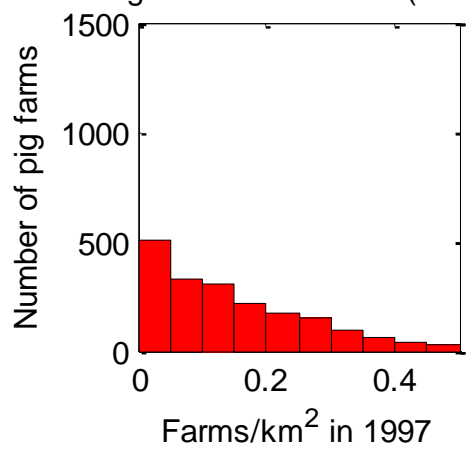

Dairy farms active in 2009

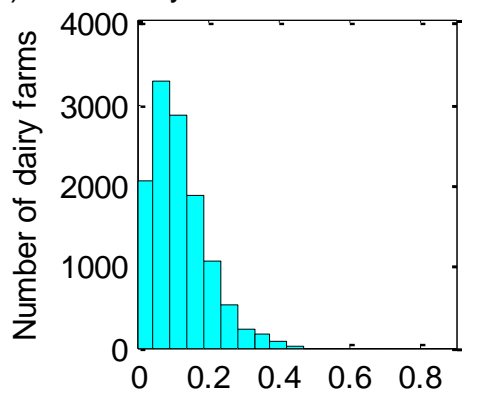

Farms $/ \mathrm{km}^{2}$ in 2009

Pig farms active in 2009

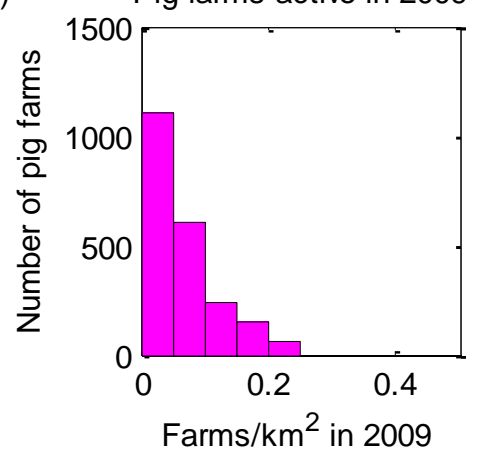

Kuva 1. Tilatiheyden (sika- tai nautatilaa/ $/ \mathrm{km}^{2} 10 \mathrm{~km}$ säteellä tilasta) jakauma kullekin 1997 toimineelle sika- ja nautatilalle sen mukaan eriteltynä, jatkoiko tila eläinten pitoa vuoteen 2009 asti, sekä tilatiheysjakauma vuonna 2009 toimineille tiloille.
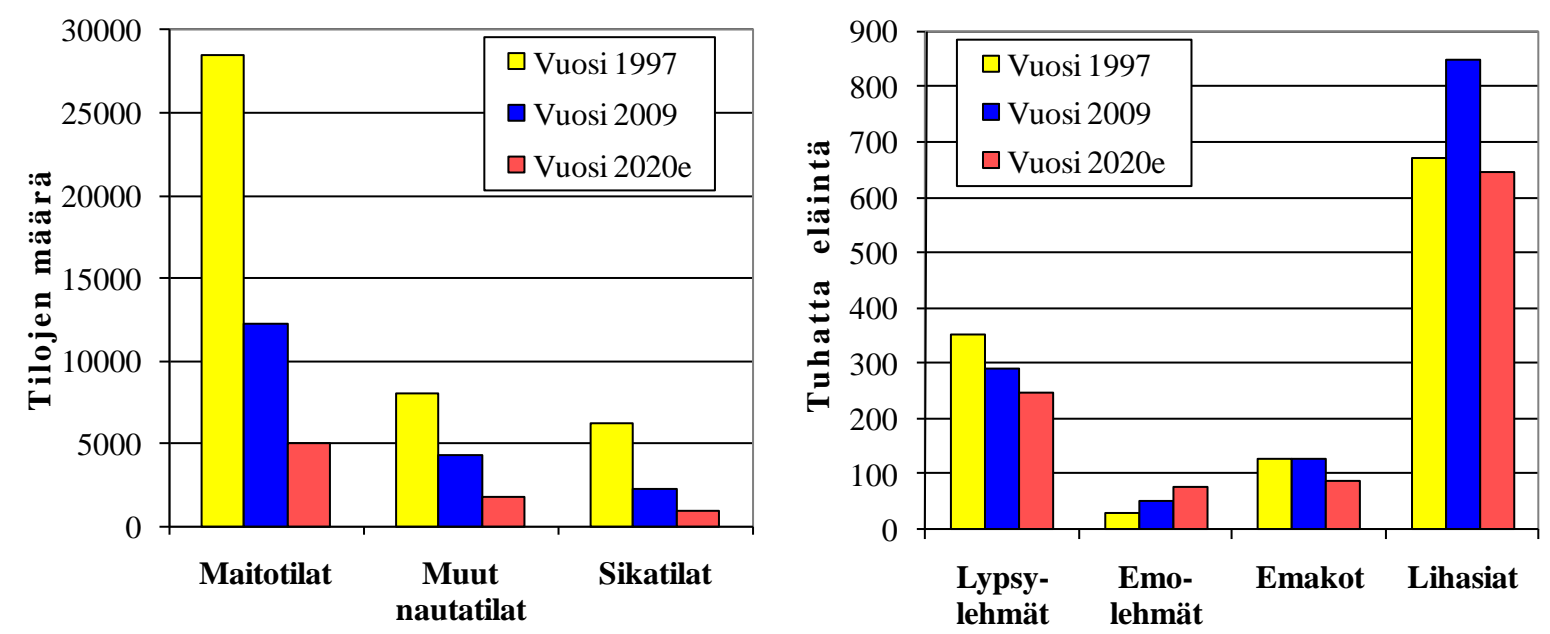

Kuva 2. Maidontuotantoa, muuta nautakarjataloutta sekä sikataloutta harjoittaneiden tilojen lukumäärät sekä lehmien ja sikojen lukumäärät Suomessa 1997 ja 2009 sekä DREMFIA-mallin ennuste vuodelle 2020 . 


\section{Tuotannon lopettaneet ja sitä jatkaneet tilat}

Logit-estimoinnin tulosten mukaan tuotannon jatkaminen vuodesta 1997 vuoteen 2009 asti oli todennäköisempää tiloilla, joilla oli vuonna 1997 sekä sikoja että nautoja. Emakoiden pito puolestaan oli yhteydessä sikojen pidon jatkumiseen ja emolehmien pito nautojen pidon jatkumiseen. Esimerkiksi sikoja ja nautoja 1997 pitäneen tilan todennäköisyys jatkaa sikatuotantoa oli 1,6-kertainen verrattuna tilaan, jolla oli pelkästään sikoja. Tuotannon jatkaminen oli myös sitä todennäköisempää mitä enemmän tilalla oli tarkastelun kohteena ollutta eläinlajia (taulukko 1).

Sikojen pidon jatkuminen oli sitä todennäköisempää, mitä sikatiheämmällä alueella tila sijaitsi, sillä yhden keskihajontayksikön lisäys alueen sikalatiheydessä lisäsi todennäköisyyttä 16,6 \%. Myös nautojen pidon jatkumisen todennäköisyys suureni hieman sikalatiheyden kasvaessa. Sen sijaan nautatilan lähistöllä sijaitsevien muiden nautatilojen määrän lisääntyessä nautojen pidon todennäköisyys pieneni. Tulos koski etenkin emolehmätuotantoa. Eläinten pidon jatkuminen ei ollut todennäköisempää meijerin tai teurastamon lähistöllä sijaitsevilla tiloilla. Taloudellisista muuttujista selvin yhteys havaittiin sikojen pidon jatkumisen kohdalla, joka laski alueen kotitalouksien tulotason kasvaessa (taulukko 1).

Tarkasteltaessa jatkaneiden nautatilojen sekä jatkaneiden sikatilojen joukkoja erikseen havaittiin, että todennäköisesti nautatila (sikatila) jatkoi niiden nautojen (sikojen) pitoa, joita sillä oli runsaasti. Tätä tulosta vahvisti se, jos tilalla oli muita saman lajin eläimiä vähän. Tilan sekatuotannolla havaittiin olevan yhteys emakoiden pidon jatkumiseen, mutta ei lehmien pidon jatkumiseen. Toisin sanoen porsaita pitävät tilat eivät todennäköisesti vaihtaneet tuotantosuuntaansa. Yhdistelmätuotannossa näytettiin erikoistuvan todennäköisemmin lihasikojen kasvatukseen kuin porsastuotantoon. Sika- tai nautatuotantoa jatkaneiden tilojen osajoukoissa lehmien ja emakoiden pidon jatkumisen todennäköisyys laski alueen kotitalouksien tulotason noustessa. Sen sijaan lypsylehmien ja emakoiden pidon jatkaminen muuttui entistä todennäköisemmäksi, kun pellon hinta tai työttömyysaste 1997 nousi tilan sijaintialueella.

Taulukko 1. Eri tekijöiden yhteys logistisessa regressiossa siihen, pitikö tila sikoja sekä 1997 että 2009 ja siihen, pitikö tila nautoja sekä 1997 että 2009. Tunnusluvut kuvaavat jatkamisen todennäköisyyttä (exp(B)) suhteessa tilaan, jolla ei ole tarkasteltua ominaisuutta.

\begin{tabular}{|c|c|c|c|c|}
\hline \multirow[b]{2}{*}{ Sikatila, jolla oli nautoja 1997} & \multicolumn{2}{|c|}{$\begin{array}{l}\text { Tila jatkoi nauto- } \\
\text { jen pitoa } 2009\end{array}$} & \multicolumn{2}{|c|}{$\begin{array}{c}\text { Tila jatkoi sikojen } \\
\text { pitoa } 2009\end{array}$} \\
\hline & & & 1,625 & $* * *$ \\
\hline Nautatila, jolla oli sikoja 1997 & 1,388 & $* * *$ & & \\
\hline Nautatilatiheys 10 km säteellä & 0,894 & $* * *$ & & \\
\hline Sikalatiheys tilaa $/ \mathrm{km}^{2} 10 \mathrm{~km}$ säteellä tilasta & & & 1,166 & $* * *$ \\
\hline Sikaloiden osuus kaikista sika- ja nautatiloista 10 km säteellä & 1,049 & $* *$ & & \\
\hline Lypsylehmien määrä tilalla 1997 & 1,631 & $* * *$ & & \\
\hline Muiden nautojen määrä tilalla 1997 & 2,112 & $* * *$ & & \\
\hline Emakoiden määrä tilalla 1997 & & & 3,188 & $* * *$ \\
\hline Muiden sikojen määrä tilalla 1997 (emakoita pitäneelle tilalle) & & & 1,178 & $* *$ \\
\hline Muiden sikojen määrä tilalla 1997 (lihasikalalle) & & & 3,845 & $* * *$ \\
\hline Kotitalouksien käytettävissä oleva tulo alueella & & & 817 & $* * *$ \\
\hline Etäisyys lähimpään teurastamoon, km & 1,115 & $* * *$ & & \\
\hline Etäisyys lähimpään meijeriin km & 1,039 & $* *$ & & \\
\hline Erikoistunut lihanautatila & 0,288 & $* * *$ & & \\
\hline Nautatila, jolla emolehmiä 1997 (dummy) & 2,380 & $* * *$ & & \\
\hline Nautatila, jolla muita nautoja 1997 (dummy) & 0,323 & $* * *$ & & \\
\hline Tila on emakkosikala (dummy) & & & 1,532 & $* * *$ \\
\hline Tila on yhdistelmäsikala (dummy) & & & 2,253 & $* * *$ \\
\hline
\end{tabular}




\section{Johtopäätökset}

Tulokset viittaavat siihen, että sika- ja nautatilojen lukumäärän vähentyminen jatkuu jokseenkin nykytahdilla. Myös eläinten määrän arvioitiin, emolehmiä lukuun ottamatta, vähentyvän lähivuosina. Muutoksissa on odotettavissa sekä alueellista, tuotantosuunnan mukaista että tilakohtaista vaihtelua. Tulokset viittaavat siihen, että kotieläintuotanto on keskittynyt ja keskittynee edelleen jossain määrin alueille, joilla sikatuotanto on vahvaa. Lisäksi tuotanto keskittyy selvästi niille tiloille, jotka ovat keskimääräistä suurempia. Tämä tulos saattaa olla yhteydessä mm. tilalla tehtyihin investointeihin ja tilan elinkaaren vaiheeseen. Todennäköisimpiä jatkajia ovat keskimääräistä suuremmat ja montaa eri tuotantosuuntaa harjoittavat tilat, jotka näyttävät ajan mittaan erikoistuvan ja valitsevan yhden päätuotantosuunnan. Tulos viittaa myös siihen, että monialaisuuteen kannustaminen tilanpidon alussa parantaa kotieläintuotannon jatkumisen edellytyksiä tilalla.

Eläinten pidon jatkaminen ei keskittynyt suurimpien teurastamoiden tai meijereiden ympäristöön. Etenkin tuotantosuuntaa valittaessa tärkeämpää näytti olevan, mitä muita työllistymismahdollisuuksia alueella on, mikä on kotitalouksien käytettävissä oleva tulotaso ja mikä on pellon vaihtoehtoiskustannus alueella. Jatkavien tilojen lisäksi aineistossa oli joukko "uusia" tiloja. Osa näistä saattoi olla esimerkiksi sukupolvenvaihdoksen tai yhtiömuodon muutoksen vuoksi uusia yrityksiä, joiden sijaintipaikalla oli saatettu harjoittaa tuotantoa jo vuonna 1997. Tärkeä havainto näidenkin tilojen osalta on, että ne olivat selvästi vuonna 2009 toiminutta keskimääräistä tilaa suurempia. Tulokset tukevatkin aikaisempia tutkimuksia tilojen keskimääräisen koon kasvusta (vrt. esim. (Hassinen 1980, Lehtonen ym. 2002, Pyykkönen ym. 2010). Sen sijaan aikaisemmissa tutkimuksissa ei ole tarkasteltu tuotannon keskittymistä samalla tarkkuudella, kuin tässä tutkimuksessa käytetyllä aineistolla oli mahdollista.

Tutkimuksissa on saatu viitteitä siitä, että kotieläintuotannon rakenne vaikuttaa merkittävästi eläintautien aiheuttamaan epidemiologiseen ja taloudelliseen riskiin. Esimerkiksi Raulon ja Lyytikäisen (2005) mukaan suurelta sikatilalta alkanut klassisen sikaruton tautipurkaus levisi hieman suuremmalle määrälle tiloja kuin pieneltä tilalta alkanut tautipurkaus. Myös sikatiheiltä alueilta alkaneen tautipurkaukset olivat suurempia kuin sikaharvoilta alueilta alkaneet tautipurkaukset. Rekisteri- ja kyselyaineistojen mukaan tilan koon ja tilatiheyden on yhteydessä tilan kontaktirakenteeseen. Lyytikäisen ym. (2011) käyttämästä tausta-aineistosta laskettujen tietojen mukaan sikatilan eläinmäärän kaksinkertaistuminen lisää eläinkuljetusautojen käyntejä tilalla 11-42 \% ja raadonkeräilyauton käyntejä 6-23 \% . Sen sijaan keinosiementäjien, eläinlääkärien ja neuvojien käynnit lisääntyvät tilakoon kaksinkertaistuessa vain hieman, minkä vuoksi eläinkuljetusten osuus kaikista tilan kontakteista lisääntyy. Myös nautatiloilla tilakoon kasvu lisää kontaktien määrää, joskin Lyytikäisen ym. (2011) mukaan muutos näyttäisi olevan sikatiloja pienempi. Maidontuotannossa kontaktimäärän kasvua kuitenkin rajoittanee se, että maitoauto käy pienimmilläkin tiloilla yleensä vähintään joka toinen päivä. Vaikka kontaktien määrä kasvaakin tilan koon kasvaessa, ei tilan koko ole yksiselitteinen taudinlevityskyvyn mittari. Tutkimuksissa on myös havaittu, että suuren riskin tilat ovat yhteydessä toisiinsa.

Tulosten mukaan tulevaisuuden todennäköisimpiä jatkajia ovat nykyiset keskimääräistä suuremmat ja monialaiset tilat, joten niiden toimintatapoihin kannattanee kiinnittää huomiota jo nykyisessä riskinhallinnan suunnittelussa. Suurissa tuotantoyksiköissä ja alueellisissa tuotantokeskittymissä eläintaudeille voi altistua entistä suurempi eläinmäärä. Tulokset yhdistettynä kirjallisuuteen viittaavatkin siihen, että jatkavilla ja uusilla tiloilla on ominaisuuksia, joiden perusteella yksittäiset tilat ovat entistä alttiimpia levittämään eläintauteja. Näitä ominaisuuksia voidaan kuitenkin heikentää riskinhallintatoimien, kuten tautisuojauksen avulla. Tällöin esimerkiksi kontaktiverkosto voi muuttaa luonnettaan ja esimerkiksi eläinkuljetusten kautta syntyvät tilojen väliset kontakti voivat harventua. Kokonaistasolla riskin muutoksen määrittäminen vaatii jatkotutkimuksia myös siksi, että tilojen määrän odotetaan vähenevän ja samalla tilojen etäisyydet toisistaan voivat kasvaa. Vaikka tilakoon kasvu lisäisikin tarttuvien eläintautien leviämisen mahdollisuuksia, voi tilojen lukumäärän vähenemisestä johtuva tilatiheyden pieneneminen vähentää tarttuvien eläintautien leviämisen riskiä. Tautiriskien hallinta ei myöskään ole yksin tilojen vastuulla, sillä esimerkiksi meijerien ja teurastamoiden vastuulla olevat maidon keräily ja teuraskuljetukset voivat muodostaa merkittävän tauteja levittävän kontaktiverkoston. Riskienhallinnan koordinoidut uudelleenjärjestelyt ovat mahdollisia, koska tuotantoketjun toimintaa suunnitellaan jo nykytilanteessa osin koordinoidusti. 


\section{Kirjallisuus}

van Asseldonk, M.A.P.M., Meuwissen, M.P.M. \& Huirne, R.B.M. 2003a. A risk financing model for livestock epidemics in the European Union. Institute for Risk Management in Agriculture, Wageningen.

van Asseldonk, M.A.P.M., Meuwissen, M.P.M., Mourits, M.C.M. \& Huirne, R.B.M. 2003b. Economics of controlling avian influenza epidemics. s. 139-148 julkaisussa: Schrijver, R.S. \& Koch, G. Proceedings of the Frontis workshop on Avian Influenza: Prevention and Control Wageningen, The Netherlands 13-15 October 2003. Saatavilla Internetissä:

Backer, J.A., Hagenaars, T.J. \& de Jong, M.C.M. 2007. Effectivity of vaccination strategies to control CSF epidemics. In: Proceedings of the SVEPM Annual Conference, 20 - 28 March, 2007, Helsinki/Espoo, Finland. Hassinen, S. 1980. Maatalouden tuotantorakenteen kehitys. MTTL Tiedonantoja N:o 66. Maatalouden taloudellinen tutkimuslaitos, Helsinki. $84 \mathrm{~s}$.

Lehtonen, H. 2004. Impacts of de-coupling agricultural support on dairy investments and milk production volume in Finland. Acta Agriculturae Scandinavica, Section C - Economy, Vol. 1. Nr. 1 / April 2004, p. 46-62.

Lehtonen, H., Pietola, K. \& Niemi, J. 2002. Maatilojen lukumäärän muutos Suomessa 1995-2000 ja arvio vuoteen 2010. MTT taloustutkimuksen selvityksiä 5/2002. Maa- ja elintarviketalouden tutkimuskeskus, Helsinki. $24 \mathrm{p}$.

Lehtonen, H. \& Pyykkönen, P. 2005. Maatalouden rakennekehitysnäkymät vuoteen 2013. MTT:n selvityksiä 100: 40 s., 1 liite. Maa- ja elintarviketalouden tutkimuskeskus, Helsinki. Saatavilla Internetissä: http://www.mtt.fi/mtts/pdf/mtts100.pdf

Luostarinen, S., Logrén, J., Grönroos, J., Lehtonen, H., Paavola, T., Rankinen, K., Rintala, J., Salo, T., Ylivainio, K. \& Järvenpää, M. (toim.), HYÖTYLANTA-tutkimusohjelman loppuraportti. MTT Raportti 21. 173 s. Maa- ja elintarviketalouden tutkimuskeskus, Jokioinen. http://www.mtt.fi/mttraportti/pdf/mttraportti21.pdf

Lyytikäinen, T. \& Kallio, E.R. 2008. Risk classification of Finnish pig farms by simulated Foot and mouth disease spread. s. 285-300 julkaisussa: Peeler, E.J., Alban, L., Russell A. and the SVEPM Executive Committee (toim.). Society for veterinary epidemiology and preventive medicine, proceedings of a meeting held at Liverpool, UK 26th-28th of March 2008.

Lyytikäinen T., Niemi J., Sahlström L., Virtanen T. \& Lehtonen H. 2011. The spread of Foot-and-mouth disease (FMD) within Finland and emergency vaccination in case of an epidemic outbreak. Evira Research Reports 1/2011. Finnish Food Safety Authority Evira, Helsinki. 147 p. http://www.evira.fi/portal/en/evira/publications/?a=view\&productId=240

Mangen, M-J.M. 2002. Economic welfare analysis of simulated control strategies for Classical Swine Fever epidemics. PhD thesis, Wageningen agricultural university. $186 \mathrm{p}$.

Pyykkönen, P., Lehtonen, H. \& Koivisto, A. 2010. Maatalouden rakennekehitys ja investointitarve vuoteen 2020. PTT:n työpapereita 125. 24 s. Pellervon taloustutkimus, Helsinki.

Raulo, S.M. \& Lyytikäinen, T. 2005. Kvantitatiivinen riskinarviointi. Klassisen sikaruton epideeminen taudinpurkaus Suomessa. EELAn julkaisuja 06/2005. Eläinlääkintä- ja elintarviketutkimuslaitos, Helsinki. 